\title{
Directions in Scenario Planning Literature - A Review of the Past Decades
}

\author{
Celeste Amorim Varuma ${ }^{*}$, Carla Meloa \\ aDepartment of Economics, Management and Industrial Engineering, University of Aveiro, \\ Campus Universitário de Santiago, 3810-193 Aveiro, Portugal
}

\begin{abstract}
This paper provides a systematized overview of patterns in the scenario planning literature published in the last decades. Recently, scenario planning has enjoyed a revival, apparent in the 'boom' in published research on the matter. Consequently, a major issue that needs to be addressed is how to organize the literature along precise lines. A number of reviews that describe the current status of the body of literature and knowledge on scenario planning have made attempts to respond to such requirements. These studies agree that systematizing the existing literature is a necessary step in developing the field. This paper aims to contribute to this purpose. The review of the academic literature here conducted is thought to be useful for both academics and practitioners. For researchers, this systematic overview will not only be constructive in providing an analysis of the directions of published research but also in setting up a research agenda for the future. For managers and practitioners, it provides a clear outline of firmrelated articles and discusses their contribution from a managerial point of view. It also raises awareness with regard to future analytical methods, and in particular, to scenario planning and its potential contribution to the competitiveness of firms.
\end{abstract}

Keywords: Future studies, Scenarios, Bibliometric Methods, management techniques

\footnotetext{
* Corresponding author. Tel.: +351 234 370361; Fax: +351 234370215.

E-mail addresses: camorim@ua.pt (C. Amorim Varum), cmelo@ua.pt (C.Melo).
} 


\section{Introduction}

Changes taking place in the business environment compel organizations and enterprises to adapt constantly to new realities, new concepts, new products, and new technologies. The identification of future trends and the anticipation of market changes have become determinant to the competitiveness of organizations. Moreover, the capacity of firms to deal with uncertainty and to adapt quickly to major changes has become a crucial factor for success and a major challenge for managers.

Managers and organizations have therefore tried to develop methods and strategies to increase their understanding of the business environment. Traditional approaches to strategy may, however, not be sufficient in such highly uncertain, intensive and complex competitive markets. According to Eisenhardt [1], under such circumstances, traditional approaches give way to 'competing on the edge', to temporary competitive advantages. Fast, high-quality, widely supported strategic decision-making processes are crucial to firms so as to succeed. Furthermore, Chermack [2] argues that the traditional strategic planning approach, while having provided some insights on how organizations can anticipate and cope with changes, has not proven its ability to inform organizational leaders about widespread political, environmental, economic and/or societal changes.

Scenario planning is an approach to strategy focused on the process, which differs from traditional approaches, often characterized as rationalistic, involving the search for the 'optimal' or 'evolutionary' strategy [3]. Scenario planning has increasingly been recommended as a tool towards the improvement of decision-making, useful in dealing with uncertainty, even in the smallest firms [1, 4]. Scenarios are based on the assumption that the business world is unpredictable, but certain events are predetermined. No scenario can provide an accurate description of the future. Their role is to help managers recognize, consider and reflect on the uncertainties they are likely to face. By identifying trends and uncertainties, a manager can construct scenarios to overcome the usual errors in decisionmaking: overconfidence and tunnel vision [5]. Scenario planning makes use of the participation of a diversity of people - experts, strategists, managers - organized in networks to create alternative representations of the future. Hence, scenario planning has been defined by Roubelat [6] as a networking process that challenges strategic paradigms and forces firms to rethink their internal and external boundaries.

According to Kees van der Heijden [3], scenario planning emerged in the aftermath of World War II as a method for military planning, and expanded to the context of social forecasting and public policy through the hands of Herman Kahn. As highlighted by Bradfield et al. [7], Kahn is often hailed in the literature as the 'father' of modern-day scenario planning. Scenario planning developed in two main geographical areas, the USA and France. In the USA, the scenario approach was introduced in the industrial field as a strategic planning tool by the Royal Dutch/Shell Group in the early 1970s by Pierre Wack. The technique was then popularized by Schwartz and Van der Hejden. In Europe, in the mid-1970s, Godet also began to develop scenarios for several institutions and companies, contributing to the development of the La Prospective school [7].

Over time, a range of terms, such as planning, thinking, analysis, and building are commonly attached to the word scenario in the literature. Godet and Roubelat [8] argue that the term is increasingly used and abused. Bradfield et al.'s [7] survey mentions literature focusing on 'scenario techniques', but at times they also call it 'literature on scenario planning'. Godet [9] suggests that, considering how he applies it, the term La Prospective is best translated as 'strategic scenario building'. Bishop et al. [10] argue that 'scenario planning' is a far more comprehensive activity and has more to do with a complete foresight study. In the words of Martelli [11], 'building scenarios means 
speculating about the uncertainty surrounding the future: basically it means envisaging a few different possible future outcomes for the situation under scrutiny'. As for scenario planning, Martelli [11] defines it as a management technology used by managers 'to articulate their mental models about the future and thereby make better decisions'. He argues that, whereas scenario building could in principle exist without scenario planning, the latter could not exist without the former. In practice, scenario building is the necessary foundation for scenario planning. While Börjeson et al. [12] refer to scenario techniques, Millet talks about scenario thinking [13]. Hence, there are subtle differences in these terms. However, we acknowledge that the terms are used interchangeably, and it seems irrelevant to exclude any at this point.

In more recent years, scenario planning has enjoyed a clear revival, apparent in the 'boom' in published research on the matter [7]. Consequently, a major issue that needs to be addressed is how to organize the literature along new, precise lines. A number of academic reviews and surveys that describe the current status of the body of literature and knowledge on scenario planning have made attempts to respond to such requirements. Chermak, Lynham and Ruona's [2] analysis of the scenario planning literature reveal several themes and objectives within the literature. Bishop, Hines and Collins [10] have instead focused on the review of methods and techniques for developing scenarios that have appeared in the literature, highlighting their utility, strengths and weaknesses. Bishop et al. further summarize contributions from some overviews of the literature. Börjeson et al. [12] create a typology of scenario techniques in predictive, exploratory and normative scenarios, which they divide into sub-categories. Bradfield et al. [7] are primarily concerned with the resolution of the 'methodological chaos' of contradictory definitions, characteristics, principles and methodological ideas found throughout the literature. They trace the origins and evolution of various methodologies and classify them into three main schools of techniques, namely intuitivelogic models, La Prospective models and the probabilistic modified trend models. They also compare the most relevant features of the schools of scenario techniques at several levels.

The reviews and surveys propose different ways to think about scenarios, but agree that systematizing and organizing the existing literature is a necessary step in developing the field and bringing the value of scenarios to a wider public. The reviews also clearly point to the need for a new, more in-depth analysis of the existing literature [10]. This paper aims to contribute to this purpose. A survey of the academic literature is conducted, in order to identify trends and to categorize the literature on several levels, thought to be useful for both academics and practitioners. For researchers, this systematic overview of the literature will not only be useful in providing an analysis of the directions of published research but also in setting up a research agenda for the future. Whereas existing surveys have focused on the scenario literature in general, our paper evolves to an in-depth analysis of a sub-sample of articles focusing particularly on firms. For practitioners, the study provides a clear outline of firm-related articles and discusses their contribution from a managerial point of view. It is also a means to raising awareness with regard to future analytical methods, and in particular, to the advantages (and disadvantages) of using scenario planning and its potential contribution to the competitiveness of firms.

The paper is organized as follows. Section 2 describes the methodology. Section 3 discusses the results and Section 4 conducts a detailed analysis of firm-related scenario articles. Section 5 concludes and points out directions for future research. 


\section{Methodology}

In our exercise, we clearly aimed to conduct a comprehensive assessment of existing academic research on scenario planning, through which we could identify the structure and main characteristics of the work developed and the knowledge created in this field. The review is based on a bibliometric study carried out through an electronic search on the ISI Web of Science platform. Quantitative and qualitative aspects of the articles identified are discussed, a method frequently suggested in the literature $[14,15]$.

The electronic searches drew on two major databases: the Science Citation Index Expanded (SCl) and the Social Sciences Citation Index (SSCI). These two databases offer high coverage of all scientific research fields, contain information about citations and the institutional addresses of all the authors of a given article, thus providing the necessary conditions to perform a deeper analysis. Furthermore, since the criterion for including a journal in $\mathrm{SCl}$ and in SSCl is the number of citations it receives, there are some guarantees as to the scientific relevance of the potential outputs [14]. Using this database implied that there was the risk of not including relevant articles published in journals not covered in the ISI in the quantitative analysis. For example, the Journal of Future Studies, Future Research Quarterly or The Futurist are not included in the ISI platform.

The period covered was the widest permitted by the ISI platform, going from 1945 to 2006. Three different key search terms were used: 'scenario planning', 'scenario building', and 'scenario thinking'. In spite of the diversity of the terminology in the literature, these are the most commonly used expressions in scenario research. This option implied running the risk of excluding from the quantitative analysis articles which did not include these expressions in the title, subject or abstract. The search was also restricted to scientific articles (194 results) published in the subject categories of 'business', 'economics', 'management', 'operations research \& management science', 'planning \& development' and 'social sciences, interdisciplinary'. The final set contained 101 documents which are listed in Appendice A. Surveying the academic literature on scenario planning is not an easy task, but we believe that our sample is sufficiently representative, so as to identify the directions taken in published academic research. It is our hope furthermore that this effort to review a representative sample of published articles may comprise a relevant step towards a rigorous account of the paths taken by scenario planning research in the last few decades.

The methodological steps taken to obtain the literature sample on which the analysis was conducted are presented in Figure 1.

\section{[Insert Figure 1 around here]}

The results were analyzed in a three-stage process. First, a quantitative analysis was conducted, based on the indicators automatically generated by the WoS platform, considering author, country/territory, institution name, language and source title. We also recorded the year of publication and number of citations, as documented by the 'Search results summary in the Web of Science.' Second, a qualitative analysis of the articles was performed, in an attempt to provide a more conceptual view of the main developments occurred in this field of research. For each article, a range of indicators was collected to create a series of cross-tabulations. The qualitative analysis of the abstracts was conducted bearing in mind the following aspects, which were selected on the basis of the literature review undertaken: (1) Research method; (2) Outputs; (3) Target group / Audience.

Regarding (1) research method, the articles were classified into theoretical, empirical or methodological, which are common classifications in the literature. Papers that explore and/or explain concepts from a theoretical perspective were classified as theoretical. Methodological papers included those that propose methods or 
improvements to existing methodologies. The articles related to specific scenario planning exercises involving the collection of primary data were considered as empirical.

The remaining taxonomies (outputs and users / target group;) were inspired by the European Foresight Monitoring Network 2005 Mapping Report [16], which maps the European foresight landscape.

Finally, an in-depth analysis was carried out of a sub-sample of articles which focused particularly on firms, in an attempt to discuss the contributions of academic research on scenario planning from a managerial point of view.

\section{Results}

In their review, Bradfield et al. [7] suggest that scenarios are now enjoying a revival in popularity, following a decline during the 1980s. Martelli [11] comes to similar conclusions, and our study corroborates this fact. After the 1990s the number of articles published per year registered considerable growth. However, around $70 \%$ of the articles considered in the analysis were published after 2000. If we look at the aggregated distribution of the articles published over a time series of five years, this growth is even more evident.

[Insert Figure 2 around here]

It is possible to identify three major journals which published articles in this field in the period considered: 'Futures' (26 percent), 'Technological Forecasting and Social Change' (15 percent) and 'Long Range Planning' (13 percent). Together, these three journals have published more than 50 percent of the articles identified. Another five journals can also be identified as having published at least two scientific articles on the matter: the Journal of the Operational Research Society, Research Technology Management, European Journal of Operational Research, International Journal of Technology Management and Sloan Management Review. Articles on scenario planning were published in another thirty-four publications across different scientific areas.

[Insert Figure 3 around here]

Kees van der Heijden is the author who has published the highest number of articles (six articles), followed by George Wright (five articles), George Burt (four articles) and Thomas Chermack (four articles). There are seven other authors who have published at least two papers on the subject of scenario planning.

However, three of the most cited articles were authored by P. J. H. Schoemaker. The articles are the following: (i) Multiple Scenario Development: Its Conceptual and Behavioural Foundation, with 40 citations, published in the Strategic Management Journal in 1993 [17]; (ii) Scenario Planning: A Tool for Strategic Thinking, with 37 citations, published in the Sloan Management Review in 1995 [5]; (iii) When and How to Use Scenario Planning: A Heuristic Approach with Illustration, with 37 citations, published in the Journal of Forecasting in 1991 [18].

Other highly cited articles are: (i) Locating Stores in Uncertain Environments: A Scenario Planning Approach, by Gosh and Mclafferty, published in the Journal of Retailing in 1982, with 25 citations [19]; (ii) Scenario Planning: What Style Should We Use, by Huss and Honton, published in Long Range Planning in 1987, with 20 citations [20]; (iii) Strategy as Strategic Decision Making, by Eisenhardt, in the Sloan Management Review in 1999, with 19 citations [1]; (iv) Constructing the Future in Planning: A Survey of Theories and Tools, by Meyers and Kitsuse, in the Journal of Planning Education and Research in 2000, with 17 citations [21], and finally, (v) The Art of Scenarios and Strategic Planning: Tools and Pitfalls, by Michel Godet, published in the Technological Forecasting and Social Change in 2000, with 16 citations [22]. 
Citations may well be related to the nature (method) of the research, and this relationship is explored in our analysis.

\section{[Insert Table 1 around here]}

With regard to the research method, the articles are mainly theoretical or empirical. Methodologically-focused papers gradually gained relevance globally over the period analyzed. As could be expected, considering that a large portion of the sample articles did not derive from flagship journals, a relatively high number of papers (33 per cent overall) were not cited in the period in consideration. On average, empirical articles received a higher rate of average citation per year, but the difference is not significant. According to Strathman [23], changes in the general orientation of research activity can be readily documented, but linking these changes to the basic incentives driving the process can prove challenging. It is not possible to observe a clear trend concerning the yearly evolution of the weight of each research method. This can raise the question as to whether a higher average of citations for empirical papers is leading authors to publish more empirically-based articles, or whether it is the opposite: i.e., is the fact that there are more authors writing empirical papers the reason why they are the most cited. The strong presence of empirical research may also result from the fact that scholars in this field often have important and extensive hands-on experience, contributing to the emergence of practical knowledge and new insights.

\section{[Insert Figure 4 around here]}

The growth of methodological research over time otherwise confirms the growth and the emergence of a plethora of scenario models and techniques. Schnaars [24] Bradfield and Bishop et al. [7, 10], for example, reveal great concern with this development. Schnaars [24] is concerned with the fact that many of these various models may be impractical and most have never been adequately tested. Bradfield and Bishop et al. [7, 10] conclude that it has resulted in a 'methodological chaos' that may prove difficult to overcome in the near future. As Marteli [11] noted, scenarios share this situation with business strategy and, to a certain extent, also with management, but their predicament is in this respect more extreme. In fact, there are some theories, principles and rules for building (and to a rather lesser extent also for planning) with scenarios. The problem is that they are vastly different and even extremely at odds with each other.

Figure 3 presents the journals with the highest number of published articles. The following graph attempts to identify predominance in terms of orientation or asymmetries between journals.

\section{[Insert Figure 5 around here]}

The two leading journals are considerably more theoretically-oriented. For the rest of the journals it is not possible to draw conclusions considering the reduced number of articles under analysis. It is worth analysing this trend in the future, and also to find plausible explanations for this fact.

Following the European Foresight Monitoring Network 2005 Mapping Report [16], we analysed the type of outputs obtained with the research conducted and published. In line with the results of the Foresight Mapping Report, we found that research and other priorities are the most common type of output (51.5 percent) of the literature analysed. Methods and scenarios are also frequent outputs, with 27.7 percent and 17.8 percent, respectively. These facts bring to mind a number of observations by Bradfield et al. [7] and Bishop et al. [10], who argue that there is a general perception that much of what has been done is of little use for practitioners. Martelli [11] goes even further in this criticism, claiming that very few authors 'venture out of the methodology they know and have applied with some success'. This has led to some scepticism or lack of trust as to their usefulness. 


\section{[Insert Figure 6 around here]}

When considering the cross-tabulation between the research method and the type of outputs, we can again observe, not surprisingly, that research and other priorities and policy recommendations result mainly from more theoretical articles, while methods are the most common output of methodological papers. The most frequent outputs from empirical articles are scenarios, analysis of trends and drivers, best practices and forecasts.

\section{[Insert Table 2 around here]}

The European Foresight Monitoring Network 2005 Mapping Report [16] divides the potential audience of future studies in research community, firms, government agencies, industry, non governmental organizations (NGOs), decision makers and general audience The analysis here conducted reveal that the research community takes the lead in terms of target group of the published articles, which is not surprising considering that our analysis focused on academic-oriented journals. Yet, we also give voice to Millett's [13] reference to the need to bring the value of scenario planning and development to a wider audience. Although scenario planning has a long history, its application in the business context is a relatively recent phenomenon [7], and our results confirm this. Firm-oriented articles represent over 47 percent of the total, and have gained significance over the years. In the period 1985/89 only 2.1 percent of the papers were firm-oriented. In the period of 2000/04, this value rose to 41.7 percent.

\section{[Insert Figure 7 around here] \\ [Insert Figure 8 around here]}

When considering the incidence of different types of articles in terms of the type of target group / users, it is possible to conclude that the articles with the highest interest for firms, industry or decision-makers are of an empirical nature, whereas articles whose end users are primarily the research community and the public in general are mainly theoretically-focused. Among the empirical studies of high interest to firms, we find two of the sources identified by Schnaars [24], particularly articles for the most part written by scenario practitioners describing how scenario planning is undertaken in large companies and offering experience-based advice on the process of carrying out scenario projects; and a body of research based on empirical studies in related topics, which offer 'some evidence as to the value of scenarios as a long-range planning tool'. Next, a more in-depth analysis of this literature is presented. [Insert Table 3 around here]

\section{Academic Research on Scenario Planning: Inputs for Firms and Managers}

In this section, a more in-depth analysis of firm-oriented articles is performed. The aim is to categorize this literature in terms of its contributions from a managerial point of view (section 5.1), and to identify the major themes under focus (section 5.2). Bradfield et al. stress the popularity of scenarios in the business context. A review of a representative sample of published articles in this domain may comprise a relevant step towards a rigorous account of the paths taken by business-oriented 'scenario research' in the last few decades.

\subsection{A taxonomy for firm-oriented literature}

An analysis of firm-oriented scenario planning literature reveals three major contributions from a managerial point of view: 'What it is and why use it'; 'How to do it and suggestions for good practice'; and 'Revealing valuable 
knowledge for managers'. These contributions arise consistently throughout the available material and are examined below.

\subsection{1. 'What is it and why use it?'}

A vast number of articles explain what scenario planning is, and point out the main advantages of the method for firms (Table 4). We have also included here the literature identified by Schnaars [24] as the body of empirical studies which offers some evidence as to the value of scenarios. This group of articles can de divided into two subgroups. One sub-group discusses scenario planning as a strategic management tool with an emphasis on the improvement of the decision-making process. This group of studies highlights that scenario planning aids planning and proactive business strategies. Scenario planning provides an opportunity to envision plausible future states (major drivers) and thus helps to generate strategies to reduce risks, to take advantage of opportunities and avoid potential threats $[25,26]$. Some of the studies suggest methods combining scenario planning with other tools such as real options $[25,27,28]$ and optimization techniques [29]. These studies also share the perception that firms operate in complex, high-commitment and high-uncertainty environments.

A second sub-group of articles focuses less on the advantages for decision- making. In line with Martelli [11], we include here articles that highlight benefits that are not so directly related with what a scenario contains but rather with how it is carried out. Winch and Arthur [30] argue that through scenario planning managers gain confidence by 'pre-experiencing' future scenarios, while Roubelat [31] mentions the role of scenario planning exercises in framing emerging ideologies based on the different beliefs of many actors. Within the firm, Winch [32] defends that scenario planning can also support the development and implementation of strategies requiring major changes, and communication of these plans to employees. This literature generally endorses scenarios as an instrument for organizational and institutional learning [33]. DeGeus [34] shows the Shell experience in this regard. Another set of studies highlights the role of scenarios in inter-organizational networks, interaction and cross-fertilization between corporate planners and external academic experts [6, 35].

Hence, bearing in mind these perspectives, our results confirm that there is a consensus in the relevant literature as to the main benefits to be derived from use of the scenario approach: improvement of the learning process, improvement of the decision-making process and the identification of new issues and problems which an organization may have to face in the future. On the other hand, no major benefits are to be expected in anticipating the future per se. Indeed, Martelli [11] argues that 'this difficult and stressing task should not really be assigned to any scenario exercise'.

The potential advantages for corporations in using scenarios are widely discussed in the literature. There is also vast body of literature on the planning-performance relationship in general. However, little evidence is available about the use and effects of scenario planning on company performance $[7,11,36]$. The studies by Malaska, Malaska et al., Meristo [37, 38, 39] in Europe and Linneman and Klein [40] on the use of scenarios by companies are notable exceptions. They reveal that up to the first oil crises, they were not widely used, but in the following period, the number of users more than doubled. They further highlight that the use of scenarios is positively related to firm size, long planning horizons and the industry's capital intensity. Martelli [11] suggests that the use of scenarios 'goes and comes in waves' and that it has increased in popularity in the last decade. This literature points to a correlation between the adoption of scenario planning and uncertainty in the business environment, but argues that scenarios 
are here to stay. On the effects of scenario planning in business, Phelps et al. [36] and Raynor and Leroux [28] are the exceptions. Phelps et al. [36] report improved financial performance resulting from scenario planning in the water industry and ICT consultancy industry in the UK. Raynor and Leroux [28] mention that 'Jupiter research' used an R\&D project selection method that draws on scenario-building and real options concepts, achieving better outcomes than could have been obtained with typical project selection methods.

\section{[Insert Table 4 around here]}

\subsection{2. 'How to' and suggestions for good practice}

A significant part of the literature analyzed describes and explains how to carry out scenario planning (Table 5). This literature was also identified by Schnaars [24]. According to this author, there are two main types of articles. Some describe how scenario planning is undertaken in (large) companies and offer experienced-based advice on the process of implementing scenario projects. Many are written by scenario planning practitioners. The articles by Pierre Wack in 1985 [41] are a good example of this line. The other type of articles offers numerous models for building scenarios, many of which are impractical and most of which never been adequately tested.

A positive aspect of this group of articles is that they put forward 'valuable planning tools for solving practical problems' under uncertainty, even in the smallest firms [4]. A common feature of these articles is that they reveal how the scenario planning methods may be adapted to different contexts given their flexibility. Recognizing that the application of scenario planning is not a panacea, a few articles focus on the 'hurdles faced in the practice of scenario planning and future studies' $[42,43,44,45,46,47]$.

[Insert Table 5 around here]

Articles on methodologies and techniques seem to have gained relevance in recent years in the literature on scenario planning in general. Also in the firm-oriented literature there is a proliferation or articles with that purpose. Bishop, Hones and Collins [10] identify and overview more than two dozen techniques, and comment on their utility, strengths and weaknesses. In this regard, Millet [13] concludes that there is such a wide variety of approaches and techniques that resolving the confusion over the definitions and methods is an essential step.

\subsection{3. 'Revealing valuable knowledge for managers'}

Finally, a relatively reduced number of articles reveal either managerial best practice for successful organizations, or future scenarios and drivers that can be used to aid planning and proactive business strategies (Table 6). These articles have in common the fact of revealing a variety of possible futures that managers might face in a variety of contexts (quality, industrial R\&D, pharmaceutical ...). Such scenarios can be useful in identifying opportunities and threats that reside in a range of possible futures. Opinions on the benefits to be gained from using scenarios in identifying new issues and problems are rather varied. As Martelli [11] notes, scenarios can be used with any time horizon but their contribution is greater or much greater in the long term.

[Insert Table 6 around here]

\subsection{Theme}

Firm-oriented publications were grouped in terms of their main subject, which were identified on the basis of the literature review undertaken. The main subjects identified were: strategic decision-making (SDM); change 
management $(\mathrm{CM})$; finance $(\mathrm{F})$; product or service development (PSD); supply-chain management and logistics (SCL); economies, government and policies (EGP); and environment (E).

As can be seen in Table 7, the share of articles concerned with strategic decision-making (which also includes, broadly speaking, aspects of strategy and strategic planning) account for over 30 percent of the publications. This trend persists over the period under analysis. Cunha et al. [48] theoretically discuss the changes occurring in the field of organizational foresight, advancing four different modes of organizational foresight. In a different line, in Wright [49], scenarios are explained and contrasted with different approaches to strategy and a scenario matrix for quality in Europe is depicted. Several examples can be found, such as Fotr and Svecova [50], Wilson [51] and Mobasheri et al. [52]. But scenario methods expanded from strategy to other functional areas of the firm, particularly to finance [25, $28,53]$, to supply-chain planning [19,54], and to product and service development [26, 55].

There is a proliferation of subjects, from change management (including learning organizations) [56, 57] to the impact of leading technological sectors in the economy, in particular, ICT-related industries $[58,59,60,61,62,63$, 64]. The latter ranges from Larson's [63] industrial research and development analysis to Randall's [62] consumer strategies for the internet, as well as technology assessment and forecasting as addressed in Thomas [64].

We can also identify a group of articles on issues related to national economies, government and policies, some of which consider scenario applications, such as the articles by Spies [65], Stokke et al. [66], Blanning and Reinig [67] or Johnston [68]. These studies promote a discussion of possibilities other than the 'most likely' one and encourage the consideration of 'what if' questions. Following Kahane [69] these scenarios are essentially a way of structuring the overwhelming information we have about the present. In Kahane words 'one of the important uses for this structure is to help us recognize more of what is going on around us, including the early, weak signals of change.'

\section{Conclusions}

In the last few decades, literature on scenarios registered considerable growth. Previous reviews of this literature are valuable in organizing the literature along themes, schools and techniques. This paper reviews the literature identifying directions of published research in scenario planning in general and that which is firm-oriented in particular.

From the bibliometric analysis accomplished, we concluded that scenario planning has gradually gained ground in international academic publications at worldwide level. Moreover, the leading authors and journals in the field were also identified.

The articles were classified according to the main research method, type of outputs and main target group. The review highlighted the strong presence of empirically-focused research, and the increasing number of publications centred on methodologies. Nevertheless, leading journals seem to be more theoretically-oriented. The causes and consequences of this trend deserve further examination. We argue that the extensive hands-on experience of many scholars in the field has contributed to this trend. Also, the efforts undertaken to develop a set of principles and practical rules, reveal an attempt to create a framework for a well-defined field of knowledge. The problem is that most methodological contributions are vastly different and even at odds with each other, giving rise to a 'methodological chaos'. 
We observed that scenarios can be applied to a variety of units of analysis and can be directed at many target groups. Firms occupy at this level a significant position. Hence, the final part of the paper comprises a more detailed analysis of firm-oriented articles and their contribution from a managerial point of view. This literature can thus be grouped under three topics: 'what is scenario planning and the advantages of its use'; 'how to carry out scenario planning' and 'reveal valuable knowledge for managers'. The articles grouped under the first topic not only define scenario planning but also focus on the benefits and gains from scenarios.

The range of applications and themes at firm level has expanded considerably from the initial strategy focus. The growing concern with the effects of the ICT revolution and environmental aspects is reflected in the emergence of papers addressing the issue, although their relative importance in scenario planning still remains relatively small.

Overall, a common feature of these articles is that they reveal how the scenario planning methods can be adapted to different contexts given their flexibility. The essential message is that the effective use of scenarios requires modesty, adaptability and persistence.

We must also point out the main limit of our study, namely that it only includes articles published in peer review journals. As noted in the methodological description, we did not consider articles published in Journals not indexed in the ISI, neither other types of research reports (conference proceedings, books, etc...). Additionally we limited our search to articles with the expressions 'scenario planning', 'scenario building' or 'scenario thinking' in the title, keywords or abstract. Both procedures eliminate some of the knowledge produced about scenarios. For these reasons, we propose that our results should not fall into abusive generalizations. Though, the results of our study highlight several avenues which would help researchers to better channel their efforts in studying the phenomenon and help managers to foster competitiveness. We summarize the main avenues in the following passages.

From our review, it is possible to identify some shortcomings in the literature. When it comes to theoretical literature, there seems to be some room for articles aimed at reviewing the field of scenarios, bringing some structure and shedding light on the matter. It is our hope that this effort to review a representative sample of published articles may contribute to a rigorous account of the paths taken by 'scenario research' in the last few decades. Future studies in this line may evolve to analysis of the articles within the lines of thought as analyzed by Bradfield et al. [7]. It would then be possible to test the hypothesis as to whether the La Prospective School has received considerably less attention in the literature, and whether there is an 'Anglo-American' domination as Godet [] states. The techniques identified by Bishop et al. [10] could then be analyzed from the perspective of those that received more attention in the literature.

At empirical level there is a notable lack of research on the use and effects of scenario planning in business. There is no empirical data in the literature which documents the popularity of scenario techniques from the early 1980s to the present day. Similarly, there is a lack of extensive studies on the effects of scenario planning on company performance and competitiveness.

The importance of an accurate assessment of the business environment for the development of a corporate strategy goes unchallenged. For managers this article raises awareness with regard to future analytical methods, and in particular, to the advantages (and disadvantages) of using scenario planning and its potential contribution to the competitiveness of firms. Such practices and techniques may well gain additional relevance in the future with the rapid rate of technological change and the role of R\&D investments, the globalization of markets, the spread of information technologies, demographic shifts, etc. [11]. The study also provides a clear outline of firm-related articles 
and discusses their contribution from a managerial point of view. In brief, the benefits gained in the decision-making process from the use of scenarios reside mainly in rendering the process more flexible, more open to criticism and more transparent. The other benefits are not so directly related with what a scenario contains but rather with how it is carried out. Managers must also be conscious that in scenario building and planning the role of techniques is important but not exclusive: the capabilities, ability and experience of the people that use the tool, as Schwartz highlighted [71], is equally important. 


\section{References}

[1] K.M. Eisenhardt, Strategy as strategic decision making, Sloan Management Review 40 (1999) 65-72.

[2] T. J. Chermack, S. A. Lynham, W. E. A. Ruona, A review of scenario planning literature, Futures Research Quarterly Summer 2001 (2001) 7-31.

[3] K. Van der Heijden, Scenarios: The Art of Strategic Conversation, John Wiley, Chichester, 1996.

[4] M.J. Foster, Scenario Planning for Small Businesses, Long Range Planning 26 (1993) 123-129.

[5] P.J.H. Schoemaker, Scenario planning - a tool for strategic thinking, Sloan Management Review 36 (1995) $25-40$.

[6] F. Roubelat, Scenario planning as a networking process, Technological Forecasting and Social Change 65 (2000) 99-112.

[7] R. Bradfielf, G. Wright, G. Burt, G. Cairns, K.V.D. Heijden, The origins and evolution of scenario techniques in long range business planning, Futures 37 (2005) 795-812.

[8] M. Godet, F. Roubelat, Creating the Future: the use and misuse of scenarios, Long Range Planning 29 (2) (1996) 164-171.

[9] M. Godet, Creating futures: scenario planning as a strategic management tool, Economica, London, (2001).

[10] P. Bishop, A. Hines, T. Collins, The current state of scenario development: an overview of techniques, Foresight 9 (1) 5-25.

[11] A. Martelli, Scenario building and scenario planning: state of the art and prospects of evolution, Futures Research Quarterly Summer (2001) 57-70.

[12] L. Börjeson, M. Höjer, K. Dreborg, T. Ekvall, G. Finnveden, Scenario types and techniques: towards a user's guide, Futures 38 (7) (2006) 723-739.

[13] S. Millett, The future of scenarios: challenges and opportunities, Strategy and Leadership 32 (2) (2003) 16-24.

[14] Social Sciences and Humanities Research Council of Canada, The use of bibliometrics in the Social Sciences and Humanities, SSHRCC, 2004.

[15] F.J. van Raan, The use of bibliometric analysis in research performance assessment and monitoring of interdisciplinary scientific developments, Technikfolgenabschätzung 1 (2003) 20-29.

[16] European Foresight Monitoring Network, Mapping Report, European Foresight Monitoring Network, 2005.

[17] P.J.H. Schoemaker, Multiple Scenario Development - Its Conceptual and Behavioural Foundation, Strategic Management Journal 14 (1993) 193-213. 
[18] P.J.H. Schoemaker, When and How to Use Scenario Planning - a Heuristic Approach with Illustration, Journal of Forecasting 10 (1991) 549-564.

[19] A. Ghosh, S.L. McLafferty, Locating Stores in Uncertain Environments - a Scenario Planning Approach, Journal of Retailing 58 (1982) 5-22.

[20] W. R. Huss, E. J. Honton, Scenario Planning - What Style Should You Use, Long Range Planning 20 (1987) 21-29.

[21] D. Myers, A. Kitsuse, Constructing the future in planning: A survey of theories and tools, Journal of Planning Education and Research 19 (2000) 221-231.

[22] M. Godet, The art of scenarios and strategic planning: Tools and pitfalls, Technological Forecasting and Social Change $65(2000)$ 3-22.

[23] J.G. Strathman, Analysis of Theoretical, Methodological and Empirical Research in the Journal of Regional Science, Journal of Regional Science 32 (1992) 501-509.

[24] S.P. Schnaars, How to develop and use scenarios, Long Range Planning 20 (1) (1987) 105-114.

[25] K.D. Miller, H. G. Waller, Scenarios, real options and integrated risk management, Long Range Planning 36 (2003) 93-107.

[26] J.H. Ahn, A. Skudlark, Managing risk in a new telecommunications service development process through a scenario planning approach, Journal of Information Technology 17(2002) 103-118.

[27] P. Cornelius, A. Van De Putte, M. Romani, Three decades of scenario planning in Shell, California Management Review 48 (2005) 92-109.

[28] M.E. Raynor, X. Leroux, Strategic flexibility in R\&D, Research-Technology Management 47 (2004) 27-32.

[29] V.A. Masch, Return to the "natural" process of decision-making leads to good strategies, Journal of Evolutionary Economics 14 (2004) 431-462.

[30] G.W. Winch, D. J. W. Arthur, User-parameterised generic models: a solution to the conundrum of modelling access for SMEs?, System Dynamics Review 18 (2002) 339-357.

[31] F. Roubelat, Scenarios to challenge strategic paradigms: Lessons from 2025, Futures 38 (2006) 519-527.

[32] G.Winch, Dynamic visioning for dynamic environments, Journal of the Operational Research Society 50 (1999) 354-361.

[33] A. Wright, Using scenarios to challenge and change management thinking, Total Quality Management \& Business Excellence 16 (2005) 87-103. 
[34] A.P. De Geus, Planning as learning, Harvard Business Review, March-April (1988) 70-74.

[35] G. Cairns, G. Wright, K. Van der Heijden, R. Bradfield, G. Burt, Enhancing foresight between multiple agencies: Issues in the use of scenario thinking to overcome fragmentation, Futures 38 (2006) 1010-1025.

[36] R. Phelps, C. Chan, S. C. Kapsalis, Does scenario planning affect performance? Two exploratory studies, Journal of Business Research 51 (2001) 223-232.

[37] P. Malaska, Multiple scenario approach and strategic behaviour in European companies, Strategic Management Journal 6 (1985) 339-355.

[38] P. Malaska, M. Malmivirta, T. Meristo, S.O. Hanson, Scenarios in Europe: Who uses them and why?, Long Rang Planning 17 (5) (1984) 45-49.

[39] T. Meristo, Not forecasts but multiple scenarios when coping with uncertainties in the competitive environment, European Journal of Operational Research 38 (1989) 350-357.

[40] R. Linneman, H.E. Klein, The use of multiple scenarios by US industrial companies, Long Range Planning, 12 (1) (1979) 83-90.

[41] P. Wack, Uncharted waters ahead, Harvard Business Review, September-October (1985) 73-89.

[42] K. Moyer, Scenario planning at British Airways - A case study, Long Range Planning 29 (1996) 172-181.

[43] J. Elkington, A. Trisoglio, Developing realistic scenarios for the environment: Lessons from Brent Spar, Long Range Planning 29 (1996) 762-769.

[44] G. Islei, G. Lockett, P. Naudé, Judgemental modelling as an aid to scenario planning and analysis, OmegaInternational Journal of Management Science 27 (1999) 61-73.

[45] G. Burt, K. van der Heijden, First steps: towards purposeful activities in scenario thinking and future studies, Futures 35 (2003) 1011-1026.

[46] J.D. Strauss, M. Radnor, Roadmapping for dynamic and uncertain environments, Research-Technology Management 47(2004) 51-57.

[47] G.P. Hodgkinson, G. Wright, Confronting strategic inertia in a top management team: Learning from failure, Organization Studies 23 (2002) 949-977.

[48] M.P.E. Cunha, P. Palma, N.G. Costa, Fear of foresight: Knowledge and ignorance in organizational foresight, Futures 38 (2006) 942-955.

[49] A.D. Wright, Scenario planning: a continuous improvement approach to strategy, Total Quality Management 11 (2000) 433-438. 
[50] J. Fotr, L. Svecova, Risk and uncertainty in strategic decision making, Politicka Ekonomie 54 (2006) 87107.

[51] I. Wilson, Strategic-Planning Isn't Dead - It Changed, Long Range Planning 27 (1994) 12-24.

[52] F.Mobasheri, L. H. Orren, F. P. Sioshansi, Scenario Planning at Southern-California Edison, Interfaces 19 (1989) 31-44.

[53] R. W Mills, B. Weinstein, Calculating shareholder value in a turbulent environment, Long Range Planning 29 (1996) 76-83.

[54] M. S. Sodhi, How to do strategic supply-chain planning, MIT Sloan Management Review 45 (2003) 69-75.

[55] J. Kiely, N. Beamish, C. Armistead, Scenarios for future service encounters, Service Industries Journal 24 (2004) 131-149.

[56] A.G. Pateli, G. M. Giaglis, Technology innovation-induced business model change: a contingency approach, Journal of Organizational Change Management 18 (2005) 167-183.

[57] S. Yearout, G. Miles, R. H. Koonce, Multi-level visioning, Training \& Development 55 (2001) 30-39.

[58] T.U. Daim, G. Rueda, H. Martin, P. Gerdsri, Forecasting emerging Technologies: use of bibliometrics and patent analysis, Technological Forecasting and Social Change 73 (2006) 981-1012.

[59] T. Sabol, R. Delina, Scenario planning, Ekonomicky Casopis 52 (2004) 942-956.

[60] M.H. Xiong, S. B. Tor, L. P. Khoo, WebATP: a Web-based flexible available-to-promise computation system, Production Planning \& Control 14 (2003) 662-672.

[61] B. Sager, Scenarios on the future of biotechnology, Technological Forecasting and Social Change 68 (2001) 109-129.

[62] D. Randall, Consumer strategies for the Internet: Four scenarios, Long Range Planning 30 (1997) 157-168.

[63] C. F. Larson, Industrial R \& D in 2008, Research-Technology Management 41 (1998) 19-24.

[64] C.W. Thomas, Strategic technology assessment, future products and competitive advantage, International Journal of Technology Management 11 (1996) 651-666.

[65] P. Spies, Experience with Futures Research in South-Africa, Futures 26 (1994) 964-979.

[66] P.R. Stokke, W.K. Ralston, T.A. Boyce, Scenario Planning for Norwegian Oil and Gas, Long Range Planning 23 (1990) 17-26.

[67] R.W. Blanning, B.A. Reinig, Building scenarios for Hong Kong using EMS, Long Range Planning 31 (1998) $900-910$ 
[68] R. Johnston, Foresight - refining the process, International Journal of Technology Management 21 (2001) $711-725$.

[69] A. Kahane, Scenarios for energy: sustainable world vs global mercantilism, Long Range Planning 25 (4) (1992) 38-46.

[70] M. Godet, Forefront: how to be rigorous with scenario planning, Foresight 2 (1) (2000) 5-9.

[71] P. Schwartz, The Art of the Long View, Doubleday/ Currency, New York, 1991. 


\section{Figures and Tables}

Figure 1: Steps followed in the identification of the literature on the WOS platform

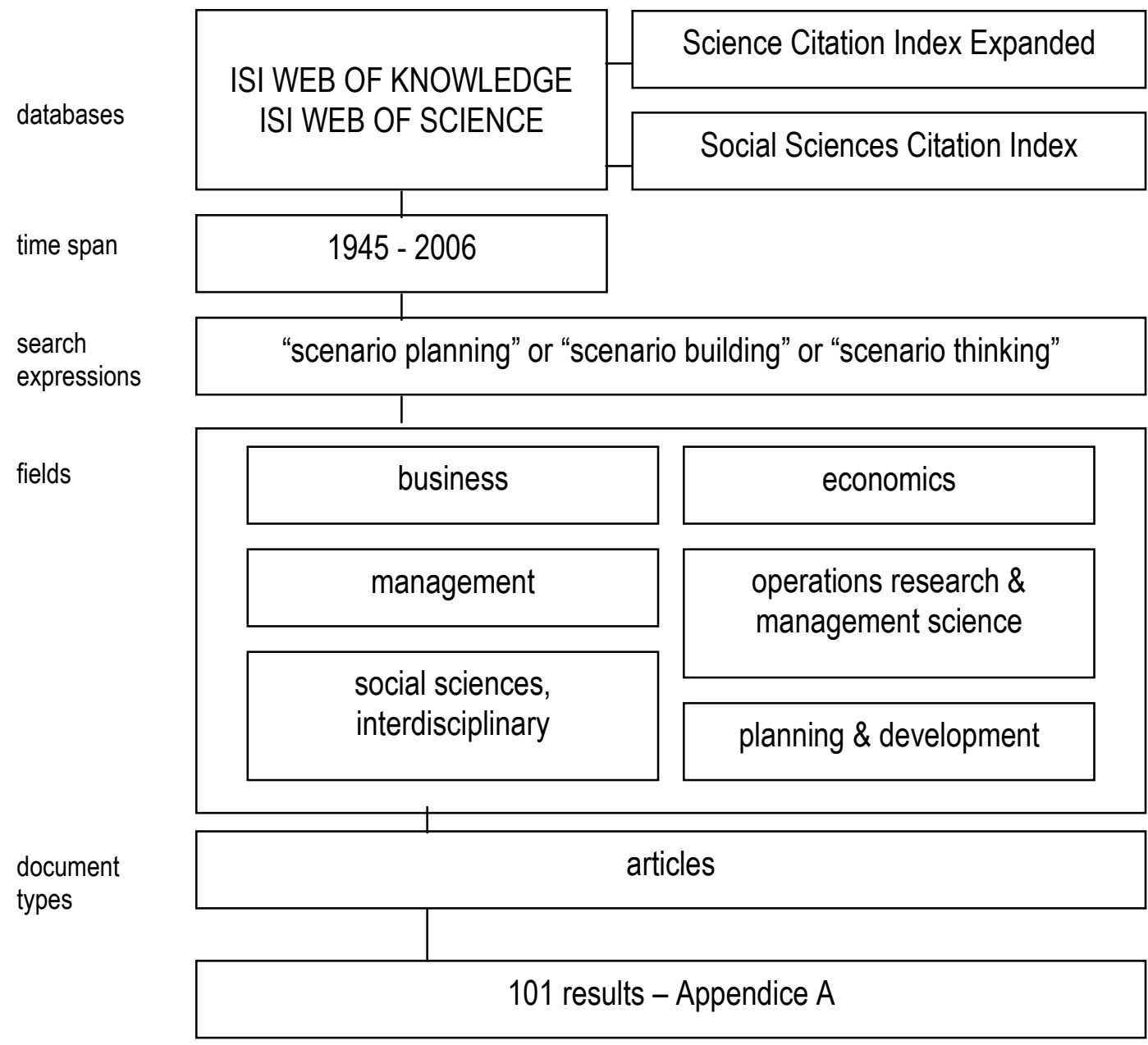

Figure 2: Number of Articles Published (time series of 5 Years)

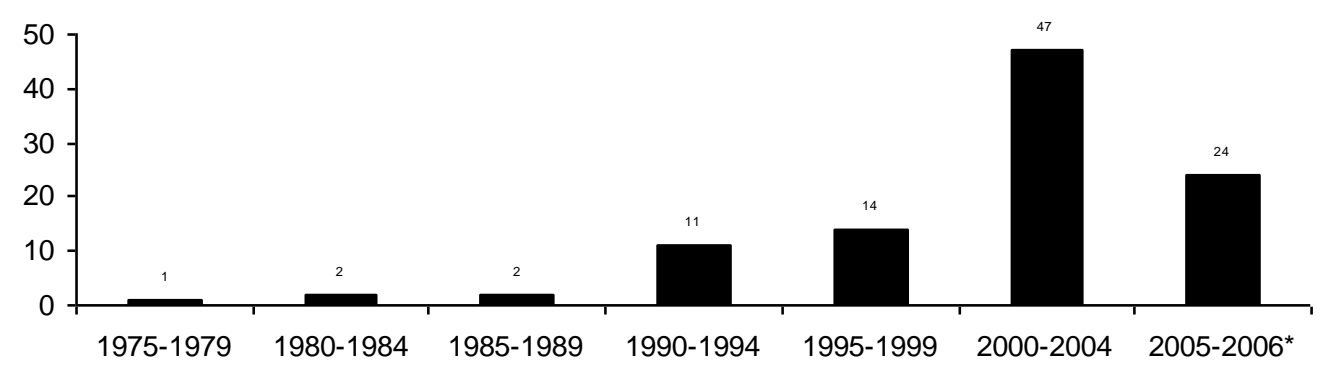

* 2005-2006 - only two years considered 
Figure 3: Articles Published by Journal (\%)

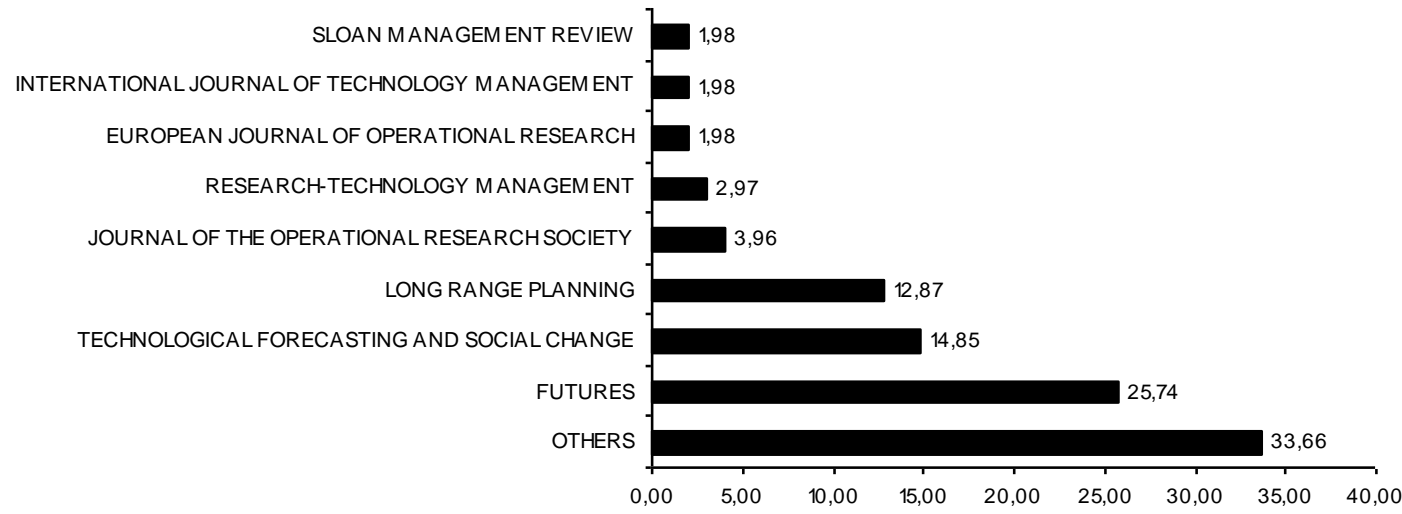

Figure 4: Distribution of Articles by Research Method per Year (time series of 5 years) (\%)

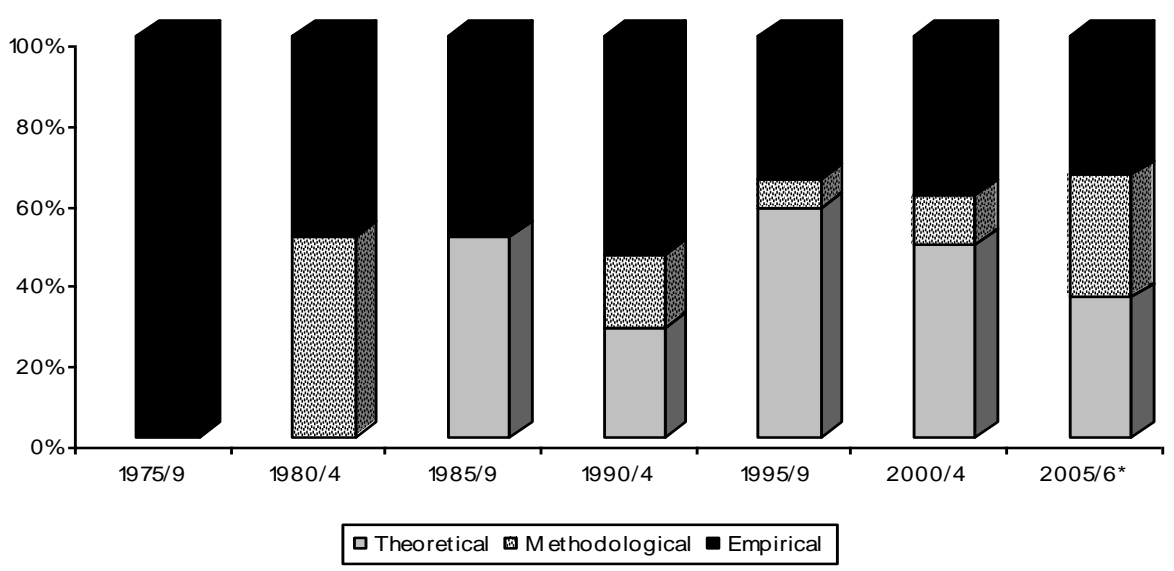

* in 2005-2006 only two years considered

Figure 5: Distribution of Articles by Research Method per Journal (\%)

Sloan Management Review International Journal of Technology Management European Journal of Operational Research Research-Technology Management Journal of Operational Research Society

Long Range Planning

Technological forecasting and social change Futures Other

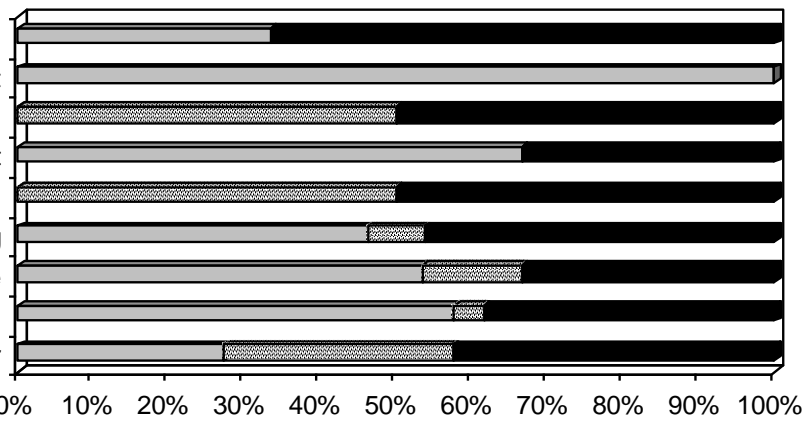

$\square$ Theoretical

Methodological

- Empirical 
Figure 6: Types of Outputs (\%)

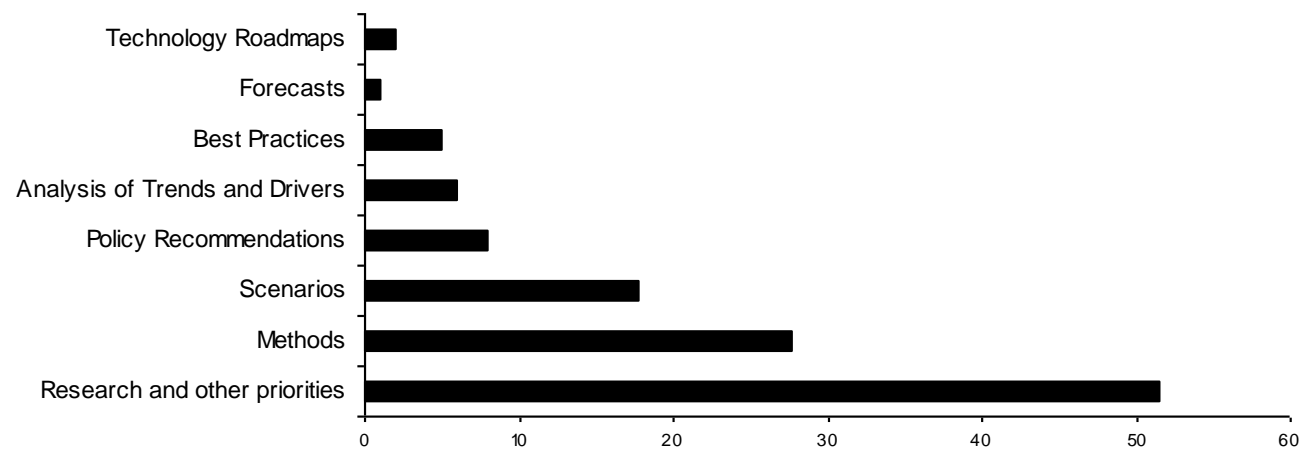

Figure 7: Articles Published by Target Group / Users (\%)

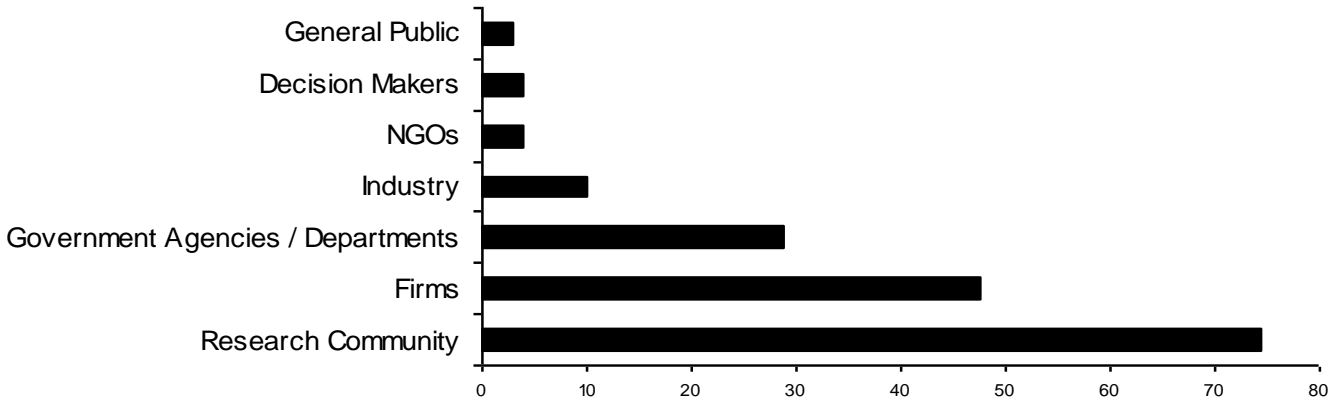

Note: Each article may have more than one class of users/target group

Figure 8: Evolution of Articles Published having Firms as main Target Group / Users (\%)

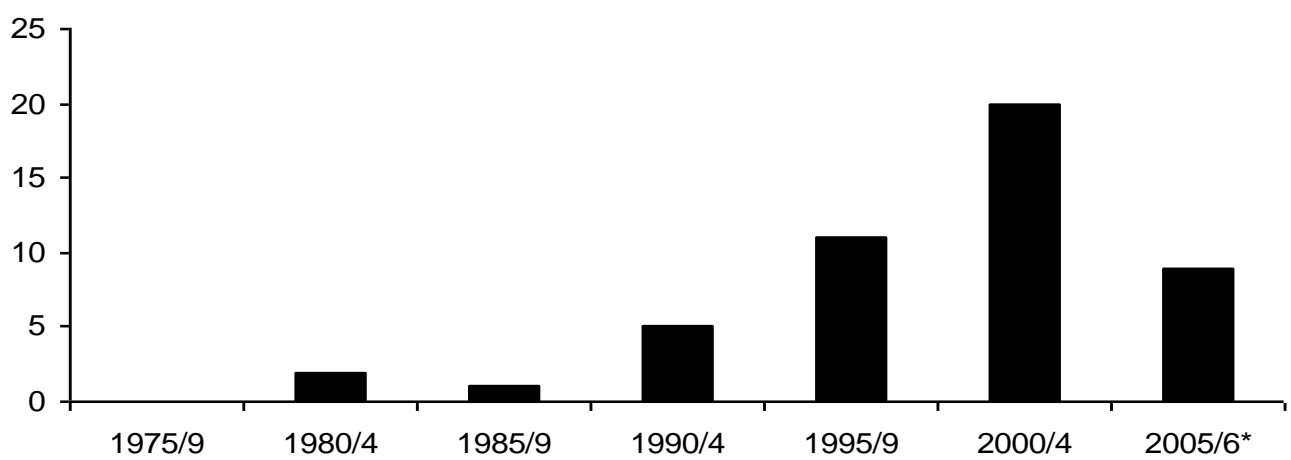

Note: $2005 / 6^{*}$ only two years

Table 1: Articles by Research Method 


\begin{tabular}{lccc}
\hline \multicolumn{1}{c}{ Research Method } & Frequency & Percent & Average Citation per Year \\
\hline Theoretical & & & 0.4677 \\
\hline Methodological & 43 & 42.6 & 0.3965 \\
\hline Empirical & 17 & 16.8 & 0.5202 \\
\hline Total & 41 & 40.6 & 0.4770 \\
\hline
\end{tabular}

Table 2: Types of Outputs by Research Method (\%)

\begin{tabular}{lcccccccc}
\hline Method & $\begin{array}{c}\text { Research and } \\
\text { other priorities }\end{array}$ & Methods & Scenarios & $\begin{array}{c}\text { Analysis of } \\
\text { Trends and } \\
\text { Drivers }\end{array}$ & $\begin{array}{c}\text { Policy } \\
\text { rec. }\end{array}$ & Forecasts & $\begin{array}{c}\text { Best } \\
\text { Practices }\end{array}$ & $\begin{array}{c}\text { Tech } \\
\text { Roadmaps }\end{array}$ \\
\hline Theoretical & 59.6 & 10.7 & 33.3 & 33.3 & 50.0 & & 40.0 & 50.0 \\
\hline Methodological & 11.5 & 50.0 & 0.0 & 0.0 & 12.5 & & & 50.0 \\
\hline Empirical & 28.8 & 39.3 & 66.7 & 66.7 & 37.5 & 100.0 & 60.0 & 100 \\
\hline TOTAL & 100 & 100 & 100 & 100 & 100 & 100 & 100 & 100 \\
\hline
\end{tabular}

Table 3: Research Method by Target Group (\%)

\begin{tabular}{lccccccc}
\hline $\begin{array}{c}\text { Method } \\
\text { of Research }\end{array}$ & $\begin{array}{c}\text { Research } \\
\text { Community }\end{array}$ & Firms & $\begin{array}{c}\text { Govt } \\
\text { Agencies / } \\
\text { Dep }\end{array}$ & Industry & NGOs & $\begin{array}{c}\text { Decision } \\
\text { Makers }\end{array}$ & $\begin{array}{c}\text { General } \\
\text { Public }\end{array}$ \\
\hline Theoretical & 46.7 & 37.5 & 27.6 & 20.0 & 50.0 & 25.0 & 66.7 \\
\hline Methodological & 22.7 & 12.5 & 17.2 & 10.0 & & 25.0 & \\
\hline Empirical & 30.7 & 50.0 & 55.2 & 70.0 & 50.0 & 50.0 & 33.3 \\
\hline TOTAL & 100 & 100 & 100 & 100 & 100 & 100 & 100 \\
\hline Note: Each article may have more than one class of users/target group & & & & &
\end{tabular}

Note: Each article may have more than one class of users/target group 
Table 4: 'What it is and why use it'

Emphasis on scenarios as technique to support decision-making

'Visionary leadership'; strategic visioning tools ... to reassess and reframe organizational vision periodically.

Scenarios support strategy related action.

Yearout et al. (2001)

Scenarios and decision-making under risk and uncertainty.

Scenario planning aids planning and proactive business strategy in service sector.

Scenario planning as strategic management tool: provides opportunity to envision plausible

future states (major drivers) helps to generate strategies to reduce risks, to take advantage of opportunities and avoid potential threats.

Scenario planning as continuous approach to strategy.

Scenario as tool for strategic planning: Overcoming common errors in decision-making: overconfidence and tunnel vision.

Scenarios used to evaluate impact of technologies on reference business model of a company or industry.

A hedge against the uncertainty of the future environment.

Scenario planning to develop resource plan.

Importance of accurate appreciation of the business environment to the development of corporate strategy.

Scenarios help to identify, exercise and evaluate real options in the future.

Optimization and scenario planning as systems for planning under uncertainty.

Fotr et al. (2006)

Kiely et al. (2004)

Miller and Waller (2003)

Ahn and Skudlark (2002)

Combining scenario planning and real options concepts as project selection method in highcommitment, high-uncertainty environments.

Scenario planning and supply-chain planning for long-term competitive advantage.

Better financial performance resulting from scenario planning.

Scenario planning improves decision-making.

Technology planning and forecasting, future products and competitive advantage.

Wright (2000)

Schoemaker (1995)

Benefits from how scenario planning is carried out

Gain confidence by 'pre-experiencing' future scenarios.

Implications of road-mapping and scenario planning on strategic-level managers.

Pateli et al. (2005)

What is organizational foresight.

Organizational learning.

Emerging ideologies (different beliefs of many actors).

Development of strategies requiring major changes, and communication of these plans to employees.

Opportunity to discuss key drivers and critical uncertainties.

Ghosh and McLafferty (1982)

Mobasheri et al. (1989)

Galer (1982)

Support inter-organizational foresight.

Creates Networks.

Networking process that challenges strategic paradigms and forces firms to rethink their internal and external boundaries.

Scenario planning: interaction and cross-fertilization between corporate planners and external academic experts.

Cornelius et al. (2005)

Masch (2004)

Raynor and Leroux (2004)

Miller and Waller (2003)

Sodhi (2003)

Phelps et al. (2001)

Eisenhardt (1999)

Thomas (1996)

Winch and Arthur (2002)

Strauss and Radnor (2004)

Cunha et al. (2006)

Chermack et al. (2006)

Wright (2005)

Roubelat (2006)

Winch (1999)

Sabol and Delina (2004)

Cairns et al. (2006)

Roubelat (2000)

Roubelat (2000)

Galer (1982) 
Table 5: 'How to'

\begin{tabular}{|c|c|}
\hline Valuable planning tools & \\
\hline Method to forecast technologies. & Narayanan et al. (2006), \\
\hline Method to set scenarios of new business models under the impact of technological innovation. & Pateli et al. 2005) \\
\hline Process of scenario planning. & Sabol and Delina (2004) \\
\hline Influence of sponsor/ leader on network. & Cairns et al. (2006) \\
\hline Interests and traps of scenario planning. & Roubelat (2006) \\
\hline Method Risk-Constrained Optimization for planning under uncertainty alternative to scenario. & Masch (2004) \\
\hline A project/portfolio selection method combining scenario planning and real options concepts. & $\begin{array}{l}\text { Raynor and Leroux (2004); } \\
\text { Miller and Waller (2003) }\end{array}$ \\
\hline Web-based flexible computation system used as 'what-if' scenario planning tool. & Xiong et al. (2003) \\
\hline How to carry out strategic supply-chain planning. & Sodhi (2003) \\
\hline Scenario planning applied to the development of a new telecommunications service concept. & Ahn and Skudlark (2002) \\
\hline Simulator to gain insights into future challenges for SMEs. & Winch and Arthur (2002) \\
\hline 'Participatory policy analysis' for foresight to improve decision-making process. & Johnston (2001) \\
\hline Scenario planning process within an organization, development of networks and support from IT. & Roubelat (2000) \\
\hline $\begin{array}{l}\text { Dynamic system simulators to simulate possible futures, and pre-experience the changed } \\
\text { environment (by contrast to static written scenarios). }\end{array}$ & Winch (1999) \\
\hline Scenarios based on electronic meeting system. & Blanning and Reinig (1998) \\
\hline Scenario planning process for building WWW related business. & Randall (1997) \\
\hline $\begin{array}{l}\text { Method to develop the Future direction of the business, using scenario thinking and strategic } \\
\text { value analysis. }\end{array}$ & Mill and Weinstein (1996) \\
\hline Step-by-step approach to build scenarios and how to use the stories to plan company's future. & Schoemaker (1995) \\
\hline Step-by-step approach to build scenarios and how to use them from a managerial perspective. & Schoemaker (1991) \\
\hline Simplified approach to scenario building which can be employed even by the smallest firms. & Foster (1993) \\
\hline $\begin{array}{l}\text { Method for Scenario-based decision-making to develop an R\&D strategy for Oil \& Gas } \\
\text { exploration and production. }\end{array}$ & Stokke et al. (1990) \\
\hline Method for scenario-based decision-making to develop resource plan. & Mobasheri et al. (1989) \\
\hline Tool for solving practical location problems for retails chains. & Ghosh and McLafferty (1982) \\
\hline Hurdles faced in practice & \\
\hline British Airways experiences in developing and using scenario planning. & Moyer (1996) \\
\hline Lessons from Shell's scenarios. & Elkington and Trisoglio (1996) \\
\hline $\begin{array}{l}\text { Effectiveness of different approaches to support group decision-making during scenarios } \\
\text { exercises. }\end{array}$ & Islei et al. (1999) \\
\hline Factors that can hinder successful design and use of scenarios. & Strauss and Radnor (2004) \\
\hline Hurdles faced in the practice of scenario planning and future studies. & Burt and Heijden (2003) \\
\hline $\begin{array}{l}\text { Reasons why scenario planning did not yield the benefits anticipated (not conductive to } \\
\text { organizational learning). }\end{array}$ & HodgKinson and Wright (2002) \\
\hline
\end{tabular}

Table 6: 'Revealing valuable knowledge for managers'

\begin{tabular}{|l|l|}
\hline Forecast technologies. & Narayanan et al. (2006), \\
\hline Scenarios and drivers for quality in Europe. & Wright (2005) \\
\hline Scenarios of future service encounters. & Kiely et al. (2004) \\
\hline Scenarios for the future of biotechnology. & Sager (2001) \\
\hline Best practices: 'visionary leadership'. & Yearout et al. (2001) \\
\hline Best- practices: 'four approaches to create strategy'. & Eisenhardt (1999) \\
\hline Scenarios for the business future of Hong Kong. & Blanning and Reinig (1998) \\
\hline Scenarios in the pharmaceutical industry. & Islei et al. (1999) \\
\hline Scenarios in industrial R\&D. & Larson (1998) \\
\hline Drivers and Scenarios for the future of the Internet. & Randall (1997) \\
\hline Futures of South Africa. & Spies (1994) \\
\hline Trends in strategic planning from 50 corporations. & Wilson, I. (1994) \\
\hline $\begin{array}{l}\text { Scenario-based decision-making to develop an R\&D strategy for Oil \& Gas exploration and } \\
\text { production. }\end{array}$ & Stokke et al. (1990) \\
\hline Electric scenario-based decision-making to develop resource plan. & Mobasheri et al. (1989) \\
\hline $\begin{array}{l}\text { Scenarios of long-term economic, social, political-strategic and technological changes affecting } \\
\text { Australia. }\end{array}$ & Galer (1982) \\
\hline
\end{tabular}


Table 7: Distribution of Firm-oriented Articles according to Main Theme and Research Method (\%)

\begin{tabular}{|l|c|c|c|c|}
\hline \multicolumn{1}{|c|}{ MAIN THEME } & \% & \multicolumn{3}{c|}{ RESEARCH METHOD } \\
\cline { 3 - 5 } & ON TOTAL & Theoretical & Methodological & Empirical \\
\hline Strategic Decision Making (SDM) & 37.0 & 29.4 & 25.3 & 47.1 \\
\hline Change Management (CM) & 15.2 & 28.6 & - & 71.4 \\
\hline Finance (F) & 8.7 & 50.0 & - & 50.0 \\
\hline Product and Service Development (PSD) & 4.4 & - & - & 100 \\
\hline Technology (T) & 13.0 & $66 .(6)$ & $16 .(6)$ & $16 .(6)$ \\
\hline Economies, Government, Policies (EGP) & 13.0 & 50.0 & - & 50.0 \\
\hline Supply-chain Management and Logistics (SCL) & 6.5 & - & $33 .(3)$ & $66 .(6)$ \\
\hline Environment (E) & 2.2 & 100 & - & - \\
\hline
\end{tabular}




\section{APPENDICE A: LIST OF ARTICLES COVERED IN THE ANALYSIS CONDUCTED}

Acar, W. and D. Druckenmiller (2006). "Endowing cognitive mapping with computational properties for strategic analysis." Futures 38(8): 993-1009.

Adam, H. and K. Moodley (1993). "Forecasting Scenarios for South-Africa." Futures 25(4): 404413.

Ahn, J. H. and A. Skudlark (2002). "Managing risk in a new telecommunications service development process through a scenario planning approach." Journal of Information Technology 17(3): 103-118.

Aligica, P. D. (2004). "The challenge of the future and the institutionalization of interdisciplinarity: notes on Herman Kahn's legacy." Futures 36(1): 67-83.

Aligica, P. D. (2005). "Scenarios and the growth of knowledge: Notes on the epistemic element in scenario building." Technological Forecasting and Social Change 72(7): 815-824.

Anderson, L. and P. Rothstein (2004). Creativity and innovation: Consumer research and scenario building. Advances in Consumer Research, Volume Xxxi. 31: 747-752.

Badiru, A. B., P. S. Pulat, et al. (1993). "Ddm - Decision-Support System for Hierarchical Dynamic Decision-Making." Decision Support Systems 10(1): 1-18.

Barbanente, A., A. Khakee, et al. (2002). "Scenario building for Metropolitan Tunis." Futures 34(7): 583-596.

Bendahan, S., G. Camponovo, et al. (2005). "Negotiation in technology landscapes: An actorissue analysis." Journal of Management Information Systems 21(4): 137-172.

Bezold, C. (1999). "Alternative futures for communities." Futures 31(5): 465-473.

Blanning, R. W. and B. A. Reinig (1998). "Building scenarios for Hong Kong using EMS." Long Range Planning 31(6): 900-910.

Borri, D., D. Camarda, et al. (2006). "Distributed knowledge in environmental planning: Hybrid ITbased approaches in scenario-building contexts." Group Decision and Negotiation 15(6): 557580 .

Bradfield, R., G. Wright, et al. (2005). "The origins and evolution of scenario techniques in long range business planning." Futures 37(8): 795-812.

Burt, G. and K. van der Heijden (2003). "First steps: towards purposeful activities in scenario thinking and future studies." Futures 35(10): 1011-1026. 
Cairns, G., G. Wright, et al. (2004). "Exploring e-government futures through the application of scenario planning." Technological Forecasting and Social Change 71(3): 217-238.

Cairns, G., G. Wright, et al. (2006). "Enhancing foresight between multiple agencies: Issues in the use of scenario thinking to overcome fragmentation." Futures 38(8): 1010-1025.

Chaturvedi, A., S. Mehta, et al. (2005). "Agent-based simulation for computational experimentation: Developing an artificial labor market." European Journal of Operational Research 166(3): 694-716.

Chermack, T. J. (2004). "Improving decision-making with scenario planning." Futures 36(3): 295309.

Chermack, T. J. (2005). "Studying scenario planning: Theory, research suggestions, and hypotheses." Technological Forecasting and Social Change 72(1): 59-73.

Chermack, T. J., S. A. Lynham, et al. (2006). "Exploring the relationship between scenario planning and perceptions of learning organization characteristics." Futures 38(7): 767-777.

Chermack, T. J. and L. van der Merwe (2003). "The role of constructivist learning in scenario planning." Futures 35(5): 445-460.

Coates, J. F. (2000). "Scenario planning." Technological Forecasting and Social Change 65(1): 115-123.

Cornelius, P., A. Van De Putte, et al. (2005). "Three decades of scenario planning in Shell." California Management Review 48(1): 92-+.

Cunha, M. P. E., P. Palma, et al. (2006). "Fear of foresight: Knowledge and ignorance in organizational foresight." Futures 38(8): 942-955.

Daim, T. U., G. Rueda, et al. (2006). "Forecasting emerging technologies: Use of bibliometrics and patent analysis." Technological Forecasting and Social Change 73(8): 981-1012.

de Jouvenel, H. (2000). "A brief methodological guide to scenario building." Technological Forecasting and Social Change 65(1): 37-48.

Dortmans, P. J. and E. Eiffe (2004). "An examination of future scenarios using historical analogy." Futures 36(10): 1049-1062.

Eisenhardt, K. M. (1999). "Strategy as strategic decision making." Sloan Management Review 40(3): 65-+.

Elkington, J. and A. Trisoglio (1996). "Developing realistic scenarios for the environment: Lessons from Brent Spar." Long Range Planning 29(6): 762-769. 
Foa, R. and M. Howard (2006). "Use of Monte Carlo simulation for the public sector - An evidence-based approach to scenario planning." International Journal of Market Research 48(1): 27-48.

Foster, M. J. (1993). "Scenario Planning for Small Businesses." Long Range Planning 26(1): 123129.

Fotr, J. and L. Svecova (2006). "Risk and uncertainty in strategic decision making." Politicka Ekonomie 54(1): 87-107.

Frentzel, W. Y., J. M. Bryson, et al. (2000). "Strategic planning in the military - The US Naval Security Group changes its strategy, 1992-1998." Long Range Planning 33(3): 402-429.

Galer, G. and W. Kasper (1982). "Scenario Planning for Australia." Long Range Planning 15(4): 50-55.

Ghosh, A. and S. L. McLafferty (1982). "Locating Stores in Uncertain Environments - a Scenario Planning Approach." Journal of Retailing 58(4): 5-22.

Godet, M. (2000). "The art of scenarios and strategic planning: Tools and pitfalls." Technological Forecasting and Social Change 65(1): 3-22.

Goodwin, P. and G. Wright (2001). "Enhancing strategy evaluation in scenario planning: A role for decision analysis." Journal of Management Studies 38(1): 1-16.

Groenenberg, H., K. Blok, et al. (2005). "Projection of energy-intensive material production for bottom-up scenario building." Ecological Economics 53(1): 75-99.

Habana, P. I. (1993). "Building Scenarios for Education in South-East Asia." Futures 25(9): 975988.

Harper, P. R., S. Phillips, et al. (2005). "Geographical simulation modelling for the regional planning of oral and maxillofacial surgery across London." Journal of the Operational Research Society 56(2): 134-143.

Harries, C. (2003). "Correspondence to what? Coherence to what? What is good scenario-based decision making?" Technological Forecasting and Social Change 70(8): 797-817.

Heemskerk, M. (2003). "Scenarios in anthropology: reflections on possible futures of the Suriname Maroons." Futures 35(9): 931-949.

Heugens, P. and J. van Oosterhout (2001). "To boldly go where no man has gone before: integrating cognitive and physical features in scenario studies." Futures 33(10): 861-872.

Hodgkinson, G. P. and G. Wright (2002). "Confronting strategic inertia in a top management team: Learning from failure." Organization Studies 23(6): 949-977. 
Huss, W. R. and E. J. Honton (1987). "Scenario Planning - What Style Should You Use." Long Range Planning 20(4): 21-29.

Islei, G., G. Lockett, et al. (1999). "Judgemental modelling as an aid to scenario planning and analysis." Omega-International Journal of Management Science 27(1): 61-73.

Janoff, S. and M. Weisbord (2006). "Future search as 'real-time' action research." Futures 38(6): 716-722.

Johnston, R. (2001). "Foresight - refining the process." International Journal of Technology Management 21(7-8): 711-725.

Kassler, P. (1995). "Scenarios for world energy: Barricades or new frontiers." Long Range Planning 28(6): 38-47.

Kiely, J., N. Beamish, et al. (2004). "Scenarios for future service encounters." Service Industries Journal 24(3): 131-149.

Larson, C. F. (1998). "Industrial R \& D in 2008." Research-Technology Management 41(6): 1924.

Lempert, R. J., D. G. Groves, et al. (2006). "A general, analytic method for generating robust strategies and narrative scenarios." Management Science 52(4): 514-528.

List, D. (2004). "Multiple pasts, converging presents, and alternative futures." Futures 36(1): 2343.

Love, A. J. and C. Russon (2000). "Building a worldwide evaluation community: past, present, and future." Evaluation and Program Planning 23(4): 449-459.

Mackay, R. B. and P. McKiernan (2004). "The role of hindsight in foresight: refining strategic reasoning." Futures 36(2): 161-179.

Masch, V. A. (2004). "Return to the "natural"process of decision-making leads to good strategies." Journal of Evolutionary Economics 14(4): 431-462.

Masini, E. B. and J. M. Vasquez (2000). "Scenarios as seen from a human and social perspective." Technological Forecasting and Social Change 65(1): 49-66.

Miller, K. D. and H. G. Waller (2003). "Scenarios, real options and integrated risk management." Long Range Planning 36(1): 93-107.

Mills, R. W. and B. Weinstein (1996). "Calculating shareholder value in a turbulent environment." Long Range Planning 29(1): 76-83.

Mobasheri, F., L. H. Orren, et al. (1989). "Scenario Planning at Southern-California Edison." Interfaces 19(5): 31-44. 
Moyer, K. (1996). "Scenario planning at British Airways - A case study." Long Range Planning 29(2): 172-181.

Myers, D. and A. Kitsuse (2000). "Constructing the future in planning: A survey of theories and tools." Journal of Planning Education and Research 19(3): 221-231.

Narayanan, V. K. and L. Fahey (2006). "Institutional evolution as an emerging focus in scenario planning." Futures 38(8): 972-992.

Neumann, I. B. and E. Overland (2001). "Perspectivistic scenario-building: history and method." Tidsskrift for Samfunnsforskning 42(3): 373-408.

O'Brien, F. A. (2004). "Scenario planning - lessons for practice from teaching and learning." European Journal of Operational Research 152(3): 709-722.

Page, S., I. Yeoman, et al. (2006). "A case study of best practice - Visit Scotland's prepared response to an influenza pandemic." Tourism Management 27(3): 361-393.

Pateli, A. G. and G. M. Giaglis (2005). "Technology innovation-induced business model change: a contingency approach." Journal of Organizational Change Management 18(2): 167-183.

Phelps, R., C. Chan, et al. (2001). "Does scenario planning affect performance? Two exploratory studies." Journal of Business Research 51(3): 223-232.

Powell, J. H. (2001). "Generating networks for strategic planning by successive key factor modification." Journal of the Operational Research Society 52(4): 369-382.

Randall, D. (1997). "Consumer strategies for the Internet: Four scenarios." Long Range Planning 30(2): 157-168.

Raynor, M. E. and X. Leroux (2004). "Strategic flexibility in R\&D." Research-Technology Management 47(3): 27-32.

Roubelat, F. (2000). "Scenario planning as a networking process." Technological Forecasting and Social Change 65(1): 99-112.

Roubelat, F. (2006). "Scenarios to challenge strategic paradigms: Lessons from 2025." Futures 38(5): 519-527.

Royston, G., J. Halsall, et al. (2003). "Operational Research for informed innovation: NHS Direct as a case study in the design, implementation and evaluation of a new public service." Journal of the Operational Research Society 54(10): 1022-1028.

Sabol, T. and R. Delina (2004). "Scenario planning." Ekonomicky Casopis 52(8): 942-956.

Sager, B. (2001). "Scenarios on the future of biotechnology." Technological Forecasting and Social Change 68(2): 109-129. 
Saxena, J. P., Sushil, et al. (1992). "Scenario Building - a Critical-Study of Energy-Conservation in the Indian Cement Industry." Technological Forecasting and Social Change 41(2): 121-146.

Schoemaker, P. J. H. (1991). "When and How to Use Scenario Planning - a Heuristic Approach with Illustration." Journal of Forecasting 10(6): 549-564.

Schoemaker, P. J. H. (1993). "Multiple Scenario Development - Its Conceptual and Behavioral Foundation." Strategic Management Journal 14(3): 193-213.

Schoemaker, P. J. H. (1995). "Scenario Planning - a Tool for Strategic Thinking." Sloan Management Review 36(2): 25-40.

Selin, C. (2006). "Trust and the illusive force of scenarios." Futures 38(1): 1-14.

Slaughter, R. A. (2002). "Futures studies as a civilizational catalyst." Futures 34(3-4): 349-363.

Sodhi, M. S. (2003). "How to do strategic supply-chain planning." Mit Sloan Management Review 45(1): $69-75$.

Spies, P. (1994). "Experience with Futures Research in South-Africa." Futures 26(9): 964-979.

Stokke, P. R., W. K. Ralston, et al. (1990). "Scenario Planning for Norwegian Oil and Gas." Long Range Planning 23(2): 17-26.

Stormer, F. (2003). "Making the shift: Moving from "ethics pays" to an inter-systems model of business." Journal of Business Ethics 44(4): 279-289.

Strauss, J. D. and M. Radnor (2004). "Roadmapping for dynamic and uncertain environments." Research-Technology Management 47(2): 51-57.

Thomas, C. W. (1996). "Strategic technology assessment, future products and competitive advantage." International Journal of Technology Management 11(5-6): 651-666.

van der Heijden, K. (2000). "Scenarios and forecasting: Two perspectives." Technological Forecasting and Social Change 65(1): 31-36.

van der Heijden, K. (2004). "Can internally generated futures accelerate organizational learning?" Futures 36(2): 145-159.

Vanston, J. H., W. P. Frisbie, et al. (1977). "Alternate Scenario Planning." Technological Forecasting and Social Change 10(2): 159-180.

Werner, M. (1990). "Planning for Uncertain Futures - Building Commitment through Scenario Planning." Business Horizons 33(3): 55-58.

Wilson, E. J. (1998). "Inventing the global information future." Futures 30(1): 23-42. 
Wilson, I. (1994). "Strategic-Planning Isnt Dead - It Changed." Long Range Planning 27(4): $12-$ 24.

Wilson, I. (2000). "From scenario thinking to strategic action." Technological Forecasting and Social Change 65(1): 23-29.

Winch, G. (1999). "Dynamic visioning for dynamic environments." Journal of the Operational Research Society 50(4): 354-361.

Winch, G. W. and D. J. W. Arthur (2002). "User-parameterised generic models: a solution to the conundrum of modelling access for SMEs?" System Dynamics Review 18(3): 339-357.

Wright, A. (2005). "Using scenarios to challenge and change management thinking." Total Quality Management \& Business Excellence 16(1): 87-103.

Wright, A. D. (2000). "Scenario planning: a continuous improvement approach to strategy." Total Quality Management 11(4-6): S433-S438.

Xiong, M. H., S. B. Tor, et al. (2003). "WebATP: a Web-based flexible available-to-promise computation system." Production Planning \& Control 14(7): 662-672.

Yearout, S., G. Miles, et al. (2001). "Multi-level visioning." Training \& Development 55(3): 30-+. 